\title{
PERAN KEPERCAYAAN PADA PEMERINTAH SEBAGAI VARIABEL MEDIASI ANTARA FAKTOR PENENTU KEPATUHAN DAN KEPATUHAN WP
}

\author{
Audrey Anugrah ${ }^{1}$ \\ Zaitul ${ }^{2}$ \\ Herawati $^{3}$ \\ Fakultas Ekonomi dan Bisnis, Universitas Bung Hatta, Padang, Indonesia 1,2,3 \\ anugrah.audrey@yahoo.com ${ }^{1}$ \\ zaitul@bunghatta.ac.id ${ }^{2}$ \\ herawati@bunghatta.ac.id ${ }^{3}$
}

\begin{abstract}
The purpose of this study was to investigate the effect of the tax payer awareness, tax payer morale and governmen power on tax compliance.besides, this study also determine the role of trust on government as a mediating variable.. The object of this research is PBB-P2 tax payers in Pasaman Barat Regency with dinal sample of 100 tax payers. This study uses primery databy disributing the questionnaires to taxpayers. Methods of data analysis is applying Structural Equation model (SEM)-PLS using Smart-pls 3.2.8. tax payer awareness has a negative effect on tax compliance. Trust on government mediated the relationship government power and tax compliance (full mediation). This study has a pratical dan theoritical implications and it discuss in this paper.
\end{abstract}

Keywords: Tax Payer Awareness, Tax Payer Morale, Government Power, Trust on Government, Tax Compliance

\begin{abstract}
Abstrak
Penelitian ini bertujuan untuk mengetahui tingkat kesadaran wajib pajak, moral wajib pajak dan kekuasaan pemerintah atas kepatuhan wajib pajak yang dimediasi oleh kepercayaan kepada pemerintah.Wajib pajak PBB-P2 Kabupaten Pasaman Barat merupakan objek dari penelitian ini, dengan 100 wajib pajak sebagai sampel. Data dikumpulkan dengan menggunakan kuesioner dan data berjenis data primer. Data dianalisa menggunakan Partial Least Square. Temuan dari penelitian ini menunjukkan bahwa tingkat kesadaran wajib pajak memiliki pengaruh terhadap kepatuhan wajib pajak. Kepercayaan kepada pemerintah dapat memediasi hubungan antara kekuasaan pemerintah dengan kepatuhan wajib pajak. Penelitian ini mempunyai implikasi teori dan praktik.
\end{abstract}

Kata kunci : Kesadaran Wajib Pajak, Moral Wajib Pajak, Kekuasaan Pemerintah, Kepercayaan Kepada Pemerintah, Kepatuhan Wajib Pajak.

\section{PENDAHULUAN}

Indonesia ialah bangsa yang sangat besar yang mengutamakan baik itu kewajiban ataupun hak dari setiap warga negara, yang berasas terhadap Pancasila dan Undang-Undang Dasar 1945. Karena itulah pajak digunakan sebagai bentuk kewajiban seorang warga negara kepada negara yang digunakan untuk membiayai segala kebutuhan ataupun pembiayaan yang digunakan untuk pembangunan yang ada di negara dan berguna serta bermanfaat bagi masyarakat luas. Banyak faktor yang dapat menghambat proses pemenuhan kewajiban seorang warga negara kepada negara yang berkaitan dengan perpajakan, salah satunya adalah kepatuhan wajib pajak. Semakin sulit beban pemerintah dalam memenuhi target pendapatan negara dalam bentuk pajak, pemerintah harus membuat kebijakan yang tepat agar target penerimaan negara dalam bentuk pajak ini dapat terpenuhi. Pemerintah mengeluarkan kebijakan yang bertujuan untuk menaikkan kepatuhan seorang wajib pajak dan untuk menunaikan pencapaian penerimaan pajak, undangundang nomor 9 dikeluarkan oleh pemerintah untuk mengganti undang-undang nomor 1 tahun 2017 yang 
membahas mengenai akses keterangan keuangan untuk keperluan perpajakan, dimana undang-undang nomor 9 ini dikeluarkan pada tanggal 23 Agustus 2017. Untuk meningkatkan sistem pendeteksian perpajakan di Indonesia, pemerintah berkomitmen untuk menerapkan kebijakan ini, hal ini juga dapat berfungsi sebagai penyempurnaan dari kekurangan metode self assesment system pada perpajakan Indonesia. Pemerintah berkemungkinan untuk dapat memeriksa rekening bank wajib pajak karena ketetapan dari undang-undang tersebut sehingga kesempatan untuk menyembunyikan informasi kekayaan yang disimpan pada rekening bank akan semakin sedikit, undang-undang ini memiliki maksud lain yaitu agar wajib pajak tidak dapat menyembunyikan kekayaannya dan menanamkan kesadaran diri bahwa mereka diawasi oleh pemerintah. Pada tanggal 31 Maret 2017 pemerintah juga menerbitkan Kartin1 yang merupakan nomor identifikasi tungal yang multi fungsi. Kartu ini bertujuan untuk mengintegrasikan fungsi dari kartu NPWP, KTP, SIM, kartu kredit, dan lain-lain. Dengan demikian penegakan undang-undang nomor 9 tahun 2017 dan Kartin1 diharapkan dapat menjadi langkah dan keputusan pemerintah yang tepat untuk meningkatkan kepatuhan wajib pajak Indonesia (Nopriyanto Hady Suhada, 2017, cnnindonesia.com).

Kepatuhan wajib pajak ialah sikap yang mengacu terhadap seorang wajib pajak yang menggambarkan tingkatan seorang wajib pajak berpegang teguh dan tidak melanggar tata tertib perpajakan yang ada dan menyelesaikan segala kewajiban pajaknya sesuai dengan peraturan yang ada dan tepat pada waktunya (Chong \& Arunachalam, 2018). Kepatuhan seorang wajib pajak ialah salah satu elemen yang berpengaruh yang berguna sebagai pemicu kenaikan perolehan pajak. Apabila semakin tinggi kepatuhan seorang wajib pajak, maka dapat memaksimalkan target perolehan pajak. Kepatuhan seorang wajib pajak ini mewujudkan keadaan wajib pajak yang berpegang teguh pada peraturan mengenai pajak yang ada, melaporkan kewajiban perpajakannya sesuai dengan keadaan sebenarnya dan membayarkan kewajiban perpajakannya tepat pada waktunya (Savitri, 2015). Kepatuhan dari seorang wajib pajak juga boleh dikatakan bagaikan sikap yang dilakukan wajib pajak sehari-hari yang menghindari atau jauh dari perlakuan dan sikap yang tidak mematuhi peraturan perpajakan yang berlaku dan melakukan kegiatan pematuhan pengakuan perpajakan hingga membayarkan kewajiban pajaknya (Braithwaite, 2007).

Negara berkembang seperti Indonesia, pada umumnya memiliki prioritas kepada pembangunan infrastruktur yang bertujuan untuk pengembangan ekonomi. Karena memprioritaskan pembangunan infrastruktur yang bertujuan untuk pengembangan ekonomi ini, maka pembiayaan yang digunakan untuk membangun infrastruktur ini sangat besar dan kebutuhan untuk pembiayaan pembangunan ini semakin besar setiap waktunya. Sumber untuk pembiayaan pembangunan ini ada yang berpangkal dari eksternal dan internal. Sumber eksternal didapatkan dari hutang luar negeri dan sumber yang berasal dari internal diperoleh melalui semua pendapatan dan penerimaan negara yang berasal dari dalam negara itu sendiri. Pemerintah selalu berusaha untuk mengurangi ketergantungan pembiayaan yang bersumber dari luar negeri dan berusaha untuk menaikkan penghasilan yang berasal dari dalam negeri, salah satu pendapatan dari dalam negeri yaitu pajak (Savitri, 2015). Pentingnya kepatuhan wajib pajak untuk tercapainya sasaran pencapaian pajak yang maksimal, semakin tinggi derajat kepatuhan seorang wajib pajak maka akan semakin tinggi pencapaian pajak suatu negara. Tingginya kepatuhan wajib pajak dan melonjaknya penerimaan pajak, lalu pendapatan negara juga semakin meningkat dan mampu membiayai pembangunan infrastruktur yang bermanfaat bagi masyarakat luas dan juga dapat mendukung untuk meningkatkan pengembangan ekonomi suatu negara (Savitri, 2015).

Tabel 1 Ketetapan dan realisasi pajak bumi dan bangunan

\begin{tabular}{c|c|c|c|c|c|c}
\hline \multirow{2}{*}{ Tahun } & \multicolumn{2}{|c|}{ Ketetapan } & \multicolumn{2}{c|}{ Realisasi } & \multicolumn{2}{c}{ Persentase } \\
\cline { 2 - 7 } & WP & Rupiah & WP & Rupiah & WP & Rupiah \\
\hline 2015 & 118.669 & 2.433 .503 .869 & 53.850 & 1.161 .972 .674 & 45,38 & 47,75 \\
\hline 2016 & 117.535 & 2.383 .644 .263 & 63.096 & 1.297 .549 .256 & 53,68 & 54,44 \\
\hline 2017 & 117.563 & 2.460 .422 .052 & 56.762 & 1.343 .515 .909 & 48,28 & 54,60 \\
\hline 2018 & 120.768 & 2.929 .818 .826 & 56.710 & 1.516 .747 .994 & 46,96 & 51,77 \\
\hline
\end{tabular}

Sumber : Badan Aset dan Pendapatan Daerah Kabupaten Pasaman Barat

Dari tabel diatas dapat dilihat bahwa ketetapan dan realisasi PBB-P2 di Kabupaten Pasaman Barat masih memiliki kesenjangan yang cukup signifikan. Setiap tahun telah ditetapkan potensi pendapatan daerah di bidang pajak salah satunya PBB-P2 yang digunakan sebagai acuan untuk mengoptimalkan pencapaian 
daerah khususnya dibidang pajak. berdasarkan tabel 1 dapat diketahui bahwa kualitas kepatuhan wajib pajak PBB-P2 di Kabupaten Pasaman Barat masih rendah, yang mengakibatkan pencapaian pajak bumi dan bangunan di Kabupaten Pasaman Barat juga masih jauh dari ketetapan yang sudah disepakati oleh pemerintah daerah, sehingga dapat mengakibatkan segala pembiayaan yang digunakan untuk pembangunan maupun belanja pemerintah khususnya pemerintah daerah dapat terhambat dikarenakan fungsi budgetair dari pajak sebagai sumber pendapatan dan dana yang berguna oleh pemerintah untuk membiayai segala pengeluaran dan belanja pemerintah. Penelitian tentang kepatuhan wajib pajak PBB masih sedikit di teliti, khususnya yang menguji peran kepercayaan pada pemerintahan sebagai variabel mediasi. Untuk itu, tujuan penelitian yaitu mebuktikan secara empiris pengaruh kesadaran wajib pajak, moral wajib pajak, kekuasaan pemerintah terhadap kepatuhan WP. Selain itu, penelitian ini juga menguji peran kepercayaan pada pemerintah dalam memediasi hubungan antara faktor penentu kepatuhan dan kepatuhan wajib pajak. Artikel ini berisikan lima bagian yaitu penduhuluan, tinjuan pustaka, metode analisa, hasil dan pembahasan, dan kesimpulan dan saran.

\section{TINJAUAN PUSTAKA}

\section{Kepatuhan Wajib Pajak}

Theory of plannerd behaviour menerangkan kalau kontrol dari sikap yang dipersepsikan atau kemampuan untuk melakukan suatu perbuatan juga mempertimbangkan sikap atas tingkah laku serta norma. Proses rasional untuk tujuan tertentu serta mengikuti urutan berpikir merupakan suatu keputusan untuk menampilkan tingkah laku yang dinyatakan dalam teori ini. Untuk membuat suatu keputusan apakah bertindak atau tidak harus mengevaluasi hasil dan konsekuensi dari setiap tingkah laku. Kemudian tujuan dari tingkah laku tersebut yang merupakan hasil refleksi dari suatu keputusan, dan banyak penelitian lain menjadi penentu cara untuk bersikap dalam situasi tertentu (Ajzen, 1991). Dalam ini sikap yang diperlihatkan oleh seseorang muncul karna ada keinginan untuk bersikap, sedangkan timbulnya keinginan bersikap ditentukan oleh tiga aspek yakni (i) Normal beliefs, merupakan motivasi dan hasrat normatif yang merupakan keyakinan seseorang untuk memuaskan hasrat tersebut (normative beliefs and motivation comply), (ii) Behavioral beliefs, merupakan evaluasi dan bentuk keyakinan seseorang atas hasil oleh suatu perilaku (beliefs strength and outcome evaluation), dan (iii) Control beliefs, merupakan situasi yang dapat menjadi penghalang ataupun mendukung sikap yang diperlihatkan mengenai keyakinan (control beliefs) dan apa yang menjadi penghambat dan persepsi mengenai seberapa kuat hal-hal yang dapat menjunjung sikap tersebut (perceived power).

Kepatuhan wajib pajak merupakan sikap kedisiplinan, komitmen dan ketertiban seorang wajib pajak kepada kebijakan perpajakan dan sistem perpajakan yang ditetapkan dan berlaku pada suatu daerah. Karena sesungguhnya setiap wajib pajak memiliki kesempatan untuk melakukan kegiatan yang bertentangan dengan kepatuhan wajib pajak andaikan wajib pajak itu tidak berkomitmen pada tata tertib dan sistem perpajakan yang diberlakukan (Braithwaite, 2007). Kepatuhan wajib pajak merupakan kecocokan dan kesesuaian antara pelaporan perpajakan dengan persyaratan dan peraturan perpajakan yang berlaku, yang artinya semua berkas yang berkaitan dengan pelaporan dan pembayaran pajak yang diberikan atau diserahkan pada waktu yang tepat dan jumlah pajak yang dibayarkan harus dengan jumlah yang tepat dan akurat (Devos, 2008). Kepatuhan wajib pajak adalah studi di bidang ekonomi yang mempelajari sikap seseorang wajib pajak dalam membuat keputusan dan memilih antara membayar atau menghindari pajak ataupun memilih untuk mematuhi segala tata tertib perpajakan yang berlaku atau tidak mematuhi tata tertib perpajakan yang berlaku (Feld \& Frey, 2002).

\section{Kesadaran Wajib Pajak}

Kesadaran wajib pajak melambangkan suatu keyakinan dan kepercayaan yang baik dari diri seorang wajib pajak dalam menunaikan pajak terutang yang dimiliki dan mengikuti semua tata tertib pajak yang berlaku. Jika wajib pajak tersebut membayar serta menyelesaikan seluruh tanggung jawab pajaknya dengan ikhlas dan setulus hati dan mengakui atau mengungkapkan semua kewajiban perpajakannya dengan jujur serta menyadari dan mengetahui bahwa pajak tersebut digunakan untuk keperluan masyarakat luas yaitu yang berkaitan dengan pembangunan dan pengembangan infrastruktur, maka para wajib pajak akan memenuhi semua kewajibannya dan mengikuti peraturan perpajakan yang berlaku dan tidak akan melakukan 
kegiatan tidak patuh (Savitri \& Musfialdy, 2016). Kesadaran seorang wajib pajak juga berkaitan dengan pemahaman dan pengetahuan seorang wajib pajak perihal aturan perpajakan maupun undang-undang yang mengatur mengenai ketentuan perpajakan, jika seorang wajib memiliki pengetahuan dan pemahan ini, dapat memungkinkan wajib pajak tersebut memenuhi kewajiiban perpajakannya yaitu dengan membayar pajak (Loo, Evans, \& Mckerchar, 2010).

\section{Moral Wajib Pajak}

Moral seorang wajib pajak sering digunakan dalam penelitian yang berhubungan dengan kepatuhan wajib pajak dan merupakan variabel yang erat kaitannya dengan kepatuhan wajib pajak. Moral wajib pajak dapat diartikan sebagai istilah umum yang berkaitan dengan orang-orang yang tidak memiliki pengetahuan tentang perpajakan, tetapi memiliki rasa dorongan untuk patuh terhadap perpajakan dan memiliki motivasi yang kuat untuk memenuhi kewajiban perpajakannya dan selalu mentaati segala peraturan perpajakan. Moral wajib pajak ialah elemen yang penting dalam mempengaruhi tingkat kepatuhan wajib pajak (Luttmer \& Singhal, 2014).

Moral wajib pajak merupakan dorongan dari dalam diri seseorang atau motivasi dari diri seorang wajib pajak untuk melaksanakan tanggung jawab perpajakannya melalui cara melunasi pajak terutangnya sehingga wajib pajak tersebut ikut membantu pemerintah untuk membiayai segala pengeluaran ataupun pembiayaan pembangunan infrastruktur yang digunakan untuk kemajuan dan perkembangan negara (Torgler, 2007). Moral wajib pajak ialah pandangan seorang wajib pajak yang memutuskan untuk taat dan patuh dan tidak curang dalam membayar pajak daripada memilih untuk curang dan tidak patuh terhadap kewajiban perpajakannya (Torgler, 2002).

\section{Kekuasaan Pemerintah}

Kekuasaan pemerintah merupakan gambaran atau anggapan seorang wajib pajak kepada pemerintah untuk dapat mengetahui dan mendeteksi segala bentuk kegiatan wajib pajak yang berkaitan dengan kegiatan tidak taat atas tanggung jawab perpajakan dari wajib pajak itu sendiri dengan cara melakukan pemeriksaan terhadap wajib pajak dan memberikan hukuman, sanksi maupun denda kepada wajib pajak yang tidak taat atas kewajiban perpajakan. Secara garis besar kekuasaan pemerintah ini berkaitan dengan undang-undang perpajakan yang dibentuk dan disusun oleh pemerintah terkait yang digunakan dan berfungsi sebagai bentuk pencegahan dan bentuk hukuman dan sanksi perpajakan untuk wajib pajak yang tidak taat terhadap kewajiban perpajakannya (Kirchler, Hoelzl, \& Wahl, 2008).

\section{Kepercayaan Kepada Pemerintah}

Dalam hal kepatuhan wajib pajak, kepercayaan mengacu kepada kepercayaan seorang wajib pajak terhadap pemerintah yang bertugas sebagai pengelola pajak. Warga negara yang merupakan wajib pajak mengharapkan agar pemerintah mengelola proses perpajakan secara efektif dan mengalokasikan pajak sebagai sumber pembiayaan pembangunan nasional. Warga negara yang merupakan wajib pajak pada akhirnya akan mematuhi peraturan perpajakan dan tidak akan melakukan penggelapan pajak dan kegiatan lainnya yang berkaitan dengan ketidakpatuhan apabila pemerintah dapat menciptakan rasa kepercayaan kepada masyarakat (Chong \& Arunachalam, 2018).

Ada beberapa langkah yang dapat ditempuh oleh pemerintah yang digunakan untuk merangkai kerja sama yang baik antara pemerintah dan masyarakatnya. Cara yang pertama yaitu dengan menggunakan hukuman atau sanksi untuk mendorong dan memotivasi rasa kepatuhan, tetapi cara ini tidak selalu berhasil digunakan untuk mempertahankan perilaku kepatuhan. Cara yang kedua yaitu dengan membangun kepercayaan masyarakat kepada pemerintah agar masyarakat memiliki perasaan dan motivasi serta dorongan mentaati semua keputusan dan prosedur yang dibuat oleh pemerintah (Kirchler et al., 2008).

\section{METODE PENELITIAN}

Penelitian ini bermaksud untuk membuktikan efek kesadaran Wajib Pajak, Moral Wajib Pajak, dan Kekuasaan Pemerintah atas Kepatuhan seorang Wajib Pajak yang dimediasi oleh Kepercayaan Kepada Pemerintah. Semua wajib PBB-P2 yang tercatat di Badan Aset dan Pendapatan Daerah Kabupaten Pasaman Barat yang berjumlah 120.768 orang dijadikan populasi. Dengan mengguanakan rumus Slovin (e=10\%) diperoleh jumlah sampel 99,92 dan kemudian dibulatkan menjadi 100. Random sampling merupakan prosedur penarikan sampel dalam penelitian ini, yang maksudnya metode penentuan sampel dilakukan 
secara acak. Berdasarkan kalkulasi di atas dapat ditentukan bahwa sampel dalam penelitian ini sejumlah 99,92 sampel, maka dibulatkan menjadi 100 sampel. Dengan demikian sebanyak 100 wajib pajak PBB-P2 yang terdaftar di Badan Aset dan Pendapatan Daerah Pasaman Barat dijadikan sampel dalam penelitian ini. Data yang digunakan pada penelitian ini ialah data primer, yang artinya data yang diterima langsung dari responden yang menjadi subjek pada penelitian melalui pengisian kuesioner. Pernyataan yang harus diisi oleh responden yang terdapat pada kuesioner untuk menilai variabel atas penelitian ini.

Metode analisis data pada penelitian ini menggunakan SEM dengan software smartPLS3. Partial Least Square (PLS) merupakan prosedur yang dapat menganilisis variabel laten, variabel indikator dan kekeliruan penilaian secara langsung (Chin, 1998). Partial Least Square (PLS) sebagai pilihan jika teori yang dipakai lemah atau indikator tidak memenuhi model pengukuran reflektif. Pemilihan metode analisa dalam penelitian ini menggunakan Partial Least Square (PLS) berdasar atas peninjauan bahwa pada penelitian ini terdapat variabel laten yang dibentuk berdasarkan beberapa indikator formative. Pengujian yang digunakan dalam Partial Least Square (PLS) dilakukan dengan dua model yaitu measurement model (outer model) dan structural model (inner model) (Vinzi, Chin, Henseler, \& Wang, 2010). Pada percobaan measurement model (outer model) menerapkan empat parameter yaitu convergent validity dan discriminant validity (Hair, Hult, Ringle, \& Sarstedt, 2017). Indicator validity dapat dilihat melalui nilai outer loading, untuk internal consistency dapat dilihat melalui cronbach's alpha dan composite reliability, untuk convergent validity dapat dilihat melalui nilai average variance extracted (AVE), dan discriminant validity dapat dilihat melalui tabel Fornell-Larcker criterion (Vinzi et al., 2010). Untuk structural model (inner model) dilihat dengan dua parameter yaitu predictive power atau R-square dan predictive relevance atau Q-square (Wong, 2013). Pengujian hipotesis menggunakan alat uji nilai $p$ dan koefisien jalur.

\section{HASIL DAN PEMBAHASAN PENELITIAN}

Sebanyak 100 kuesioner telah disebar pada penelitian ini. proses penyebaran kuesioner dengan mendatangi responden secara langsung dan mendatangi kediaman atau rumah wajib pajak itu sendiri yang pengambilannya ditunggu ataupun dijemput oleh peneliti dengan tempat dan waktu yang sudah ditetapkan sesuai oleh kesepakatan antara responden dengan peneliti serta 86 kuesioner yang kembali dapat diolah.

\section{Outer Model Validitas Convergent}

Tabel 3 Measurement Model

\begin{tabular}{|c|c|c|c|c|c|}
\hline Construct & Item & Outer Loding & Cronbach's Alpha & $\begin{array}{l}\text { Composite } \\
\text { Reliability }\end{array}$ & AVE \\
\hline \multirow{5}{*}{$\begin{array}{c}\text { Kepatuhan } \\
\text { Wajib Pajak }\end{array}$} & KWP 1 & 0.843 & \multirow{5}{*}{0,901} & \multirow{5}{*}{0,926} & \multirow{5}{*}{0,715} \\
\hline & KWP 2 & 0.865 & & & \\
\hline & KWP 3 & 0.919 & & & \\
\hline & KWP 4 & 0.838 & & & \\
\hline & KWP 5 & 0.755 & & & \\
\hline \multirow{4}{*}{$\begin{array}{l}\text { Kesadaran } \\
\text { Wajib Pajak }\end{array}$} & K1 & 0.891 & \multirow{4}{*}{0,920} & \multirow{4}{*}{0,943} & \multirow{4}{*}{0,806} \\
\hline & K2 & 0.957 & & & \\
\hline & K3 & 0.897 & & & \\
\hline & K4 & 0.842 & & & \\
\hline \multirow{8}{*}{$\begin{array}{l}\text { Moral Wajib } \\
\text { Pajak }\end{array}$} & M3 & 0.781 & \multirow{8}{*}{0,915} & \multirow{8}{*}{0,928} & \multirow{8}{*}{0,617} \\
\hline & M4 & 0.739 & & & \\
\hline & M5 & 0.743 & & & \\
\hline & M7 & 0.869 & & & \\
\hline & M9 & 0.709 & & & \\
\hline & M10 & 0.868 & & & \\
\hline & M11 & 0.810 & & & \\
\hline & M12 & 0.747 & & & \\
\hline
\end{tabular}




\begin{tabular}{|c|c|c|c|c|c|}
\hline \multirow{3}{*}{$\begin{array}{l}\text { Kekuasaan } \\
\text { pemerintah }\end{array}$} & KP3 & 0.812 & \multirow{3}{*}{0,889} & \multirow{3}{*}{0,932} & \multirow{3}{*}{0,820} \\
\hline & KP4 & 0.943 & & & \\
\hline & KP5 & 0.955 & & & \\
\hline \multirow{5}{*}{$\begin{array}{l}\text { Kepercayaan } \\
\text { Kepada } \\
\text { Pemerintah }\end{array}$} & KKP 1 & 0.850 & \multirow{5}{*}{0,900} & \multirow{5}{*}{0,926} & \multirow{5}{*}{0,715} \\
\hline & KKP 2 & 0.905 & & & \\
\hline & KKP 3 & 0.839 & & & \\
\hline & KKP 4 & 0.797 & & & \\
\hline & KKP 5 & 0.832 & & & \\
\hline
\end{tabular}

Sumber : Lampiran, data diolah

Tabel diatas menampilkan nilai outer loading, cronbach's alpha, composite reliability dan nilai AVE oleh setiap item variabel yang terdapat pada penelitian ini. Item-item yang terdapat dalam tabel di atas merupakan item yang telah valid yang memiliki nilai outer loading, cronbach's alpha dan composite reliability $>0,7$ serta nilai $A V E>0,5$. Item-item valid ini diperoleh setelah melakukan penghapusan item yang tidak valid karena tidak sesuai dengan kriteria dan kemudian melakukan re-calculate hingga mendapatkan item yang valid.

\section{Validitas Diskriminan}

Tabel 4 Fornell-Lacker Criterion

\begin{tabular}{c|c|c|c|c|c}
\hline & $\begin{array}{c}\text { Kekuasaan } \\
\text { Pemerinta } \\
\mathrm{h}\end{array}$ & $\begin{array}{c}\text { Kepatuhan } \\
\text { Wajib Pajak }\end{array}$ & $\begin{array}{c}\text { Kepercayaan } \\
\text { Kepada } \\
\text { Pemerintah }\end{array}$ & $\begin{array}{c}\text { Kesadaran } \\
\text { Wajib } \\
\text { Pajak }\end{array}$ & $\begin{array}{c}\text { Moral } \\
\text { Wajib } \\
\text { Pajak }\end{array}$ \\
\hline Kekuasaan Pemerintah & $\mathbf{0 . 9 0 6}$ & & & & \\
\hline Kepatuhan Wajib Pajak & 0.336 & $\mathbf{0 . 8 4 6}$ & & & \\
\hline Kepercayaan Kepada Pemerintah & 0.771 & 0.438 & $\mathbf{0 . 8 4 5}$ & & \\
\hline Kesadaran Wajib Pajak & -0.003 & -0.236 & -0.119 & $\mathbf{0 . 8 9 8}$ & \\
\hline Moral Wajib Pajak & 0.238 & 0.055 & 0.124 & 0.292 & $\mathbf{0 . 7 8 5}$ \\
\hline
\end{tabular}

Sumber : Lampiran, data diolah

Sesuai berdasarkan perolehan pengujian discriminant validity diketahui jika nilai koefisien korelasi setiap variabel laten sudah berada diatas 0.70 . Hasil menunjukan bahwa tiap-tiap variabel penelitian sudah didukung dengan item pernyataan yang tepat dan handal, sehingga tahap pengolahan data selanjutnya bisa dilakukan.

Tabel 5 Cross Loading

\begin{tabular}{|c|c|c|c|c|c|}
\hline & $\begin{array}{l}\text { Kekuasaan } \\
\text { Pemerintah }\end{array}$ & $\begin{array}{l}\text { Kepatuhan } \\
\text { Wajib Pajak }\end{array}$ & $\begin{array}{l}\text { Kepercayaan } \\
\text { Kepada } \\
\text { Pemerintah }\end{array}$ & $\begin{array}{c}\text { Kesadaran } \\
\text { Wajib Pajak }\end{array}$ & $\begin{array}{l}\text { Moral } \\
\text { Wajib } \\
\text { Pajak }\end{array}$ \\
\hline KP3 & 0.812 & & & & \\
\hline KP4 & 0.943 & & & & \\
\hline KP5 & 0.955 & & & & \\
\hline KWP1 & & 0.842 & & & \\
\hline KWP2 & & 0.866 & & & \\
\hline KWP3 & & 0.918 & & & \\
\hline KWP4 & & 0.837 & & & \\
\hline KWP5 & & 0.757 & & & \\
\hline KKP1 & & & 0.850 & & \\
\hline KKP2 & & & 0.905 & & \\
\hline KKP3 & & & 0.839 & & \\
\hline KKP4 & & & 0.797 & & \\
\hline KKP5 & & & 0.833 & & \\
\hline K1 & & & & 0.891 & \\
\hline K2 & & & & 0.957 & \\
\hline
\end{tabular}


Vol. 5 No. 1, Maret 2020

\begin{tabular}{c|c|c|c|c|c}
\hline & $\begin{array}{c}\text { Kekuasaan } \\
\text { Pemerintah }\end{array}$ & $\begin{array}{c}\text { Kepatuhan } \\
\text { Wajib Pajak }\end{array}$ & $\begin{array}{c}\text { Kepercayaan } \\
\text { Kepada } \\
\text { Pemerintah }\end{array}$ & $\begin{array}{c}\text { Kesadaran } \\
\text { Wajib Pajak }\end{array}$ & $\begin{array}{c}\text { Moral } \\
\text { Wajib } \\
\text { Pajak }\end{array}$ \\
\hline K3 & & & & $\mathbf{0 . 8 9 7}$ & \\
\hline K4 & & & & $\mathbf{0 . 8 4 2}$ & \\
\hline M10 & & & & & $\mathbf{0 . 8 6 8}$ \\
\hline M12 & & & & & $\mathbf{0 . 8 1 0}$ \\
\hline M3 & & & & & $\mathbf{0 . 7 4 7}$ \\
\hline M4 & & & & & $\mathbf{0 . 7 8 1}$ \\
\hline M5 & & & & & $\mathbf{0 . 7 3 9}$ \\
\hline M9 & & & & & $\mathbf{0 . 7 4 3}$ \\
\hline
\end{tabular}

Sumber : Lampiran, data diolah

Bersumber dari tabel di atas terlihat kalau setiap item pernyataan yang mendukung setiap variabel sudah mempunyai nilai cross loading sama dengan atau diatas 0.70 dengan demikian setiap item pernyataan sudah mempunyai tingkat ketepatan yang baik sehingga dapat terus digunakan. Oleh karena itu tingkatan pengolahan data selanjutnya dapat dilakukan.

\section{Inner Model}

Pada percobaan structural model (inner model) ini digunakan untuk meninjau interaksi antar konstruk, nilai signifikansi, $R$-square dan Q-square dari model atas penelitian ini. Model struktural (inner model) pada PLS ini dinilai memakai nilai $R$-square dan path coeffecients. Model struktural penelitian ini bisa diamati pada diagram jalur berikut ini :

\section{Gambar 1 Output diagram jalur bootstraping}

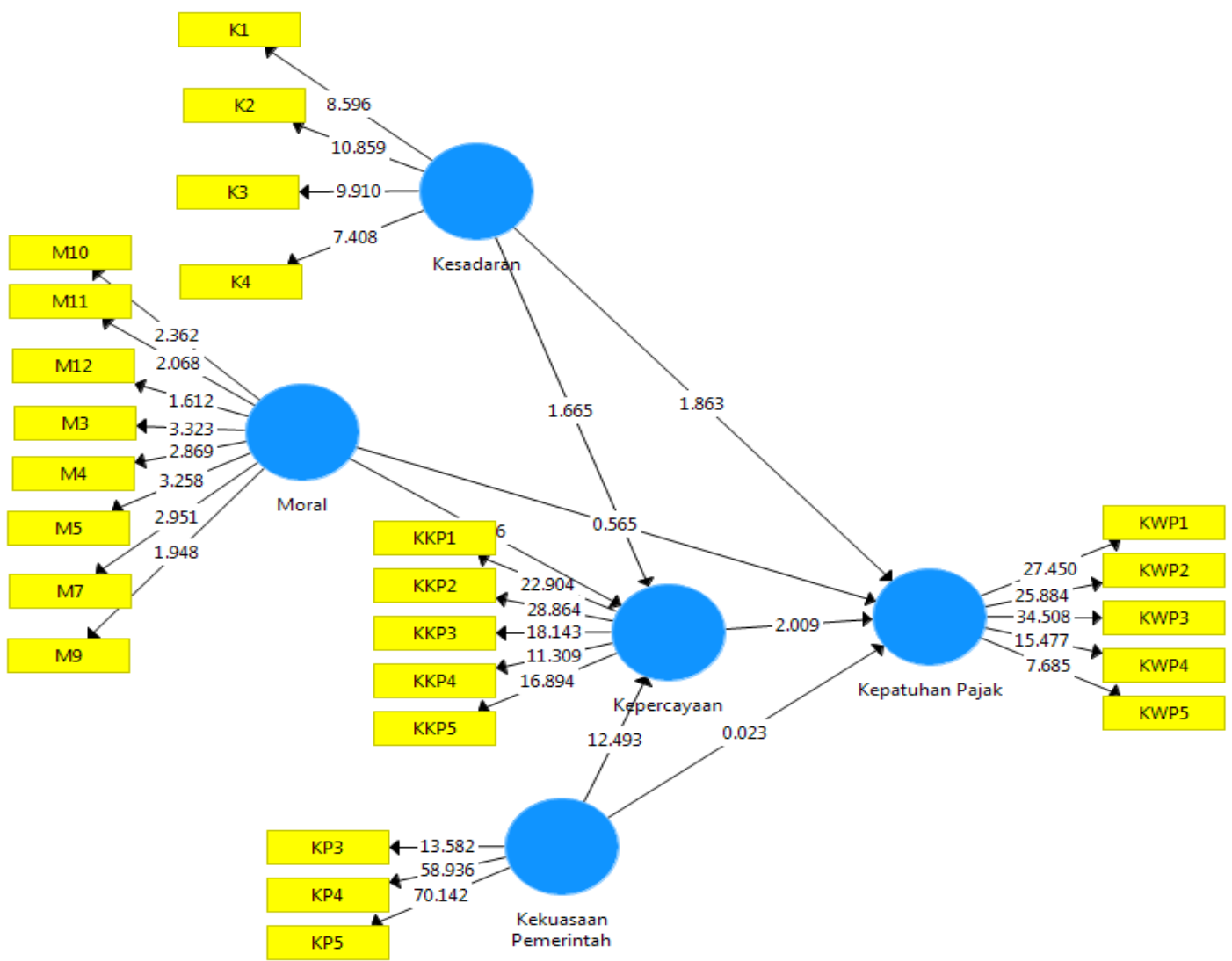




\begin{tabular}{c|c|c}
\hline & $R$-square & Q-square \\
\hline Kepatuhan Wajib Pajak (Y) & 0,226 & 0,139 \\
\hline Kepercayaan Kepada Pemerintah (Z) & 0,609 & 0,384 \\
\hline
\end{tabular}

Sumber : Lampiran, data diolah

Pada tabel ini menunjukkan bahwa pengaruh model X1, X2 dan X3 dalam mempengaruhi model Z menghasilkan $R$-square dengan nilai 0,609 . Hal ini bermakna kalau variabel $Z$ yang bisa dijelaskan oleh variabel X1, X2, dan X3 adalah sebesar 60,9\% serta 39,1\% lainnya dijelaskan oleh variabel lain diluar model yang digunakan dalam penelitian ini. Pada tabel ini juga menunjukkan nilai $R$-square untuk model $Y$ yang menghasilkan nilai $R$-square yang bernilai 0,226 . Berarti variabel $Y$ yang dapat dideskripsikan oleh variabel X1, X2 dan X3 melalui variabel Z adalah sebesar 22,6\% serta 77,4\% lainnya dijelaskan oleh variabel lain diluar model yang digunakan dalam penelitian ini.

Tabel 7 Nilai Path Coefficient Indirect dan Direct Effect

\begin{tabular}{c|c|c|c}
\hline & $\begin{array}{c}P \text { - } \\
\text { Values } \\
\text { Indirec } \\
\boldsymbol{t}\end{array}$ & $\begin{array}{c}\text { P-Values } \\
\text { Direct }\end{array}$ & Kesimpulan \\
\hline $\begin{array}{c}\text { Kesadaran Wajib Pajak } \rightarrow \text { Kepercayaan Kepada Pemerintah } \rightarrow \\
\text { Kepatuhan Wajib Pajak }\end{array}$ & 0,255 & 0,063 & $\begin{array}{c}\text { Direct only } \\
\text { non } \\
\text { mediation }\end{array}$ \\
\hline $\begin{array}{c}\text { Moral Wajib Pajak } \rightarrow \text { Kepercayaan Kepada Pemerintah } \rightarrow \\
\text { Kepatuhan Wajib Pajak }\end{array}$ & 0,648 & 0,572 & $\begin{array}{c}\text { No effect } \\
\text { non } \\
\text { mediation }\end{array}$ \\
\hline $\begin{array}{c}\text { Kekuasaan Pemerintah } \rightarrow \text { Kepercayaan Kepada Pemerintah } \rightarrow \\
\text { Kepatuhan Wajib Pajak }\end{array}$ & 0,046 & 0,982 & $\begin{array}{c}\text { Indirect only } \\
\text { mediation }\end{array}$ \\
\hline
\end{tabular}

Sumber : Lampiran, data diolah

\section{Pengaruh Kesadaran Wajib Pajak terhadap Kepatuhan Wajib Pajak}

Kesadaran wajib pajak adalah sikap dari seorang wajib pajak yang memiliki keyakinan atau kepercayaan yang baik untuk membayar pajak. Jika seorang wajib pajak memenuhi kewajiban perpajakannya dengan setulus hati dan juga jujur dalam pengungkapan perpajakannya serta menyadari dan mengetahui seberapa penting pajak digunakan untuk perkembangan dan pembangunan yang berguna bagi masyarakat luas, maka para wajib pajak tidak akan melakukan praktik tidak taat atau patuh terhadap segala kebijakan dan aturan perpajakan (Savitri \& Musfialdy, 2016). Hasil analisis hipotesis membuktikan kalau terdapat efek kesadaran seorang wajib pajak atas kepatuhan seorang wajib pajak. Hal ini bisa ditinjau melalui nilai $P$-values pada pengujian path coefficient yang memperoleh nilai $0,063<0,10$. Hasil penelitian ini sebanding dengan penelitian Chong \& Arunachalam (2018) dimana kepatuhan seorang wajib pajak dapat dapat dipengaruhi oleh kesadaran wajib pajak. Hal ini juga sebanding atas penelitian yang dilakukan oleh Aswati, dkk (2018) dengan hasil kalau kesadaran dari seorang wajib pajak dapat berdampak atas kepatuhan seorang wajib pajak. Hasil ini memperlihatkan ketika seorang wajib pajak menyadari seberapa penting pajak dipakai kepada pembiayaan pembangunan infrastruktur yang dapat bermanfaat untuk masyarakat luas dan wajib pajak tersebut mempunyai pengetahuan serta pendidikan tentang perpajakan maka akan mempengaruhi tingkat kepatuhan seorang wajib pajak tersebut.

\section{Pengaruh Moral Wajib Pajak terhadap Kepatuhan Wajib Pajak}

Moral wajib pajak bisa diartikan sebagai istilah umum yang berkaitan dengan orang-orang yang tidak memiliki pengetahuan tentang perpajakan, tetapi memiliki rasa dorongan untuk patuh terhadap perpajakan dan kuatnya motivasi yang dimiliki untuk memenuhi kewajiban perpajakannya dan selalu mentaati segala peraturan serta undang-undang perpajakan yang berlaku (Luttmer \& Singhal, 2014). Hasil analisis hipotesis 
pada penelitian ini memperlihatkan kalau tidak adanya efek moral wajib pajak atas kepatuhan wajib pajak. Hal ini bisa diamati melalu nilai $P$-values pada pengujian path coefficient yang memperoleh nilai 0,572 >0,10. Kepatuhan seorang wajib pajak tidak memiliki pengaruh dengan moral seorang wajib pajak disebabkan oleh motivasi dan dorongan seorang wajib pajak untuk memenuhi tanggung jawab perpajakan tidak murni berasal dari dalam diri seorang wajib pajak, Karna sesuai dengan teori atribusi menurut Sarwono (2004) dalam penelitian Ramadhan (2017) membuktikan kalau sikap seseorang dapat ditimbulkan berdasarkan aspek internal atau eksternal, bentuk aspek eksternal ini bagaikan dampak dari orang lain, maksudnya ialah individu terpaksa bersikap untuk memenuhi tanggung jawab perpajakannya karena suatu kondisi dan pengaruh dari orang sekitar, sehingga dorongan dan motivasi untuk taat atas perpajakan tidak murni dari dalam diri wajib pajak tersebut. temuan pada penelitian ini sebanding atas temuan Chong \& Arunachalam (2018) dan Ramadhan (2017) dimana moral wajib pajak tidak mempunyai pengaruh atas kepatuhan seorang wajib pajak. Hal ini menunjukkan kalau tingkatan moral seorang wajib pajak tidak mempengaruhi kepatuhan seorang wajib pajak.

\section{Pengaruh Kekuasaan Pemerintah terhadap Kepatuhan Wajib Pajak}

Kekuasaan pemerintah berkaitan dengan undang-undang perpajakan yang dibentuk dan disusun oleh pemerintah terkait yang digunakan dan berfungsi sebagai bentuk pencegahan dan bentuk hukuman dan sanksi perpajakan untuk wajib pajak yang tidak mematuhi tanggung jawab pajaknya (Kirchler et al., 2008). Hasil analisis hipotesis pada penelitian ini memperlihatkan kalau tidak adanya efek antara kekuasaan pemerintah atas kepatuhan wajib pajak. Hal ini bisa diamati melalui nilai $P$-values pada pengujian path coefficient yang memperoleh nilai 0,982 $>0,10$. Kepatuhan seorang wajib pajak tidak bisa dipengaruhi atas kekuasaan pemerintah, karena sejalan atas Theory of Planned Behavior (Ajzen, 1991) yang menjelaskan kalau seseorang yang merupakan wajib pajak memilih untuk taat atau tidak mematuhi tata tertib perpajakan perpajakan berlandaskan oleh niat untuk berperilaku taat atau tidak taat kepada tata tertib perpajakan yang berjalan.

\section{Pengaruh Kesadaran Wajib Pajak terhadap Kepatuhan Wajib Pajak yang dimediasi Kepercayaan Kepada Pemerintah.}

Hasil analisis hipotesis menunjukkan kalau kepercayaan kepada pemerintah tidak dapat meperantarai hubungan antara kesadaran terhadap kepatuhan dari seorang wajib pajak. Hal ini dapat diketahui melalui nilai $P$-values pada pengujian path coefficient yang memperoleh nilai $0,255>0,10$. Bersumber dari hasil analisis tersebut bahwa dapat diketahui kepercayaan seorang wajib pajak tidak selalu menciptakan kesadaran, sehingga seorang yang memiliki kesadaran seberapa pentingnya pajak itu digunakan untuk kepentingan orang banyak tetapi disatu kondisi pemerintah tidak dapat menanamkan rasa kepercayaan kepada masyarakatnya atau pemerintah membentuk rasa kepercayaan masyarakatnya dengan cara menggunakan hukuman atau sanksi, sehingga kepercayaan masyarakat kepada pemerintah tidak dapat memediasi kesadaran seorang wajib pajak untuk taat terhadap tanggung jawab pajaknya dan aturan perpajakan yang berlaku. Hasil penelitian ini sebanding atas penelitian Chong \& Arunachalam (2018), yang menyatakan kalau kepercayaan kepada pemerintah tidak memediasi hubungan antara kesadaran seorang wajib pajak dengan kepatuhan seorang wajib pajak.

\section{Pengaruh Moral Wajib Pajak terhadap Kepatuhan Wajib Pajak yang dimediasi Oleh Kepercayaan Kepada Pemerintah}

Hasil analisis hipotesis pada penelitian ini menunjukkan kalau kepercayaan kepada pemerintah tidak memediasi keterkaitan antara moral wajib pajak dengan kepatuhan seorang wajib pajak. Ini dapat diketahui melalui nilai $p$-values pada pengujian path coefficient yang memperoleh nilai $0,646>0,10$. Dari hasil analisis tersebut diketahui bahwa seorang wajib pajak yang mempunyai moral atau motivasi serta dorongan yang kuat dari dalam dirinya tidak selamanya mereka percaya terhadap pemerintah yang berkuasa dapat mengelola dan menggunakan pajak yang telah dibayarkan untuk kepentingan orang banyak dan untuk pembangunan negara, sehingga wajib pajak yang memiliki motivasi dan hasrat dari dalam dirinya untuk menyetor pajak menjadi tidak ingin memenuhi kewajiban perpajakan dan tidak mentaati aturan perpajakan yang berlaku, sehinga kepercayaan kepada pemerintah tidak dapat memediasi hubungan antara moral seorang wajib pajak terhadap kepatuhan wajib pajak. Temuan pada penelitian ini sependapat atas penelitian 
oleh Chong \& Arunachalam (2018), dimana kepercayaan kepada pemerintah tidak dapat memediasi hubungan antara moral wajib pajak dengan kepatuhan seorang wajib pajak.

\section{Pengaruh Kekuasaan Pemerintah terhadap Kepatuhan Wajib Pajak yang dimediasi Oleh Kepercayaan Kepada Pemerintah}

Hasil analisis hipotesis atas penelitian ini menunjukkan kalau kepercayaan kepada pemerintah dapat meperantarai hubungan kekuasaan pemerintah dengan kepatuhan dari seorang wajib pajak. Hal ini bisa diketahui melalui nilai $P$-values pada pengujian path coefficient yang memperoleh nilai 0,046 $<0,10$. Berdasarkan hasil analisis tersebut dapat diketahui bahwa kekuasaan pemerintah yang kuat adalah pemerintah yang mampu menegakkan aturan-aturan yang berlaku dengan baik, ketika pemerintah mampu menciptakan sistem yang baik dan juga memberikan sanksi yang tepat bagi mereka yang melanggar aturan, maka akan dapat menciptakan nilai kepercayaan kepada masyarakat, selain itu juga para aparatur pemerintahan sebagai orang yang dicontoh oleh masyarakatnya harus juga ikut mematuhi segala aturan yang berlaku. Ketika pemerintah dapat menggunakan kekuasaannya dengan baik dan juga menciptakan rasa kepercayaan kepada masyarakat maka akan menaikkan kepatuhan masyarakatnya sebagai seorang wajib pajak untuk memenuhi tanggung jawab pajak dan menaati peraturan perpajakan. Sehingga kepercayaan kepada pemerintah dapat memediasi hubungan antara kekuasaan pemerintah dengan kepatuhan seorang wajib pajak. Berdasarkan hasil analisis tersebut juga dapat diketahui bahwa apabila seorang wajib pajak memiliki kepercayaan kepada pemerintah, maka akan terjalin interaksi kerja sama yang saling menguntungkan antara wajib pajak dengan pemerintah sehingga kepatuhan seorang wajib pajak saat melaksanakan pemenuhan tanggung jawab pajak dapat ditingkatkan. Kepatuhan seorang wajib pajak bisa dicapai atas peningkatan level kekuasaan pemerintah dan kepercayaan kepada pemerintah. Disuatu kondisi apabila kepercayaan terhadap pemerintah dan kekuasaan pemerintah lemah, maka sangat memungkinkan wajib pajak berusaha melakukan penghindaran pajak dan pastinya membuat kepatuhan wajib pajak juga ikut melemah. Peningkatan kepercayaan kepada pemerintah dapat meningkatkan kekuasaan pemerintah karena wajib pajak mendukung pemerintah sehingga mempermudah tugas pemerintah dalam melaksanakan tugasnya (Kirchler et al., 2008). Hasil peneltian ini sejalan dengan penelitian yang dilakukan oleh Chong \& Arunachalam (2018), dimana kepercayaan kepada pemerintah dapat memediasi hubungan antara kekuasaan pemerintah dengan kepatuhan seorang wajib pajak.

\section{SIMPULAN DAN SARAN}

Berdasarkan pembahasan serta hasil analisis, bahwa bisa disimpulkan seperti berikut (i) Kepatuhan seorang wajib pajak bisa dipengaruhi oleh kesadaran seorang wajib pajak dan Kepercayaan Kepada Pemerintah dapat memperantarai ikatan antara Kekuasaan Pemerintah dengan Kepatuhan Wajib Pajak PBB-P2 Kabupaten Pasaman Barat. Adapun beberapa saran diuraikan sebagai berikut (i) Diharapkan untuk Penelitian selanjutnya menambah prosedur data dikumpulkan selain kuesioner seperti wawancara supaya mendapatkan data yang makin objektif, (ii) Penelitian selanjutnya agar menambah variabel independen dan variabel lainnya, karena penelitian ini hanya menggunakan tiga variabel independen yaitu kesadaran wajib pajak, moral wajib pajak dan kekuasaan pemerintah dan satu variabel mediasi yaitu kepercayaan kepada pemerintah, dan (iii) Penelitian selanjutnya diharapkan dapat memperluas daerah penelitiannya atau daerah pengambilan sampel, sehingga dapat mewakili populasi yang lebih luas lagi.

\section{DAFTAR PUSTAKA}

Ajzen, I. (1991). The Theory of Planned Behavior. Organizational Behavior and Human Decision Proccess, 50, 179-211. Aswati, W. O., Mas'ud, A., \& Nudi, T. N. (2018). Pengaruh Kesadaran Wajib Pajak, Pengetahuan Pajak, dan Akuntabilitas Pelayanan Terhadap Kepatuhan Wajib Pajak Kendaraan Bermotor. Jurnal Akuntansi Dan Keuangan, III(1), 27-39.

Braithwaite, V. (2007). Responsive Regulation and Taxation : Introduction. Law \& Policy, 29(1).

Chin, W. (1998). The partial least squares approach to structural equation modeling in G. A. Marcoulides (Ed.). In Modern methods for business research (pp. 295-236). London: Lawrence Erlbaum Associates.

Chong, K.-R., \& Arunachalam, M. (2018). Determinants of Enforced Tax Compliance: Empirical Evidence From Malaysia. Advances in Taxation, 25, 147-172. https://doi.org/10.1108/S1058-749720180000025007

Devos, K. (2008). Tax Evasion Behaviour and Demographic Factors : An Exploratory Study in Australia. Revenue Law 
Journal, 18(1).

Feld, L. P., \& Frey, B. S. (2002). Trust Breeds Trust : How Taxpayers Are Treated. Economics of Governance, 3, 87-99.

Hair, J. F., Hult, G. T. M., Ringle, C. M., \& Sarstedt, M. (2017). A primer on partial least squares structural equation modeling (PLS-SEM). Los Angeles: SAGE Publication. https://doi.org/10.1017/CBO9781107415324.004

Kirchler, E., Hoelzl, E., \& Wahl, I. (2008). Enforced versus voluntary tax compliance : The "' slippery slope "' framework. Journal of Economic Psychology, 29, 210-225. https://doi.org/10.1016/j.joep.2007.05.004

Loo, E. C., Evans, C., \& Mckerchar, M. (2010). Challenges in Understanding Compliance Behaviour of Taxpayers in Malaysia. Asian Journal of Business and Accounting, 3(2), 101-118.

Luttmer, E. F. P., \& Singhal, M. (2014). Tax Morale. Journal of Economic Perspectives, 28(4), 149-168.

Savitri, E. (2015). The Effect of Tax Socialization , Tax Knowledge , Expediency of Tax ID Number and Service Quality on Taxpayers Compliance With Taxpayers Awareness as Mediating Variables. Procedia-Social and Behavioral Sciences, 211, 163-169. https://doi.org/10.1016/j.sbspro.2015.11.024

Savitri, E., \& Musfialdy. (2016). The Effect of Taxpayer Awareness, Tax Socialization, Tax Penalties, Compliance Cost at Taxpayer Compliance with Service Quality as Mediating Variable. Procedia-Social and Behavioral Sciences, 219, 682-687. https://doi.org/10.1016/j.sbspro.2016.05.051

Torgler, B. (2002). Speaking To Theorists and Searching For Facts : Tax Morale, 16(5), 657-683.

Vinzi, V. E., Chin, W. W., Henseler, J., \& Wang, H. (2010). Handbook of Partial Least Square: Concepts, Methods and Applications. Berlin, German: Springer. https://doi.org/10.1007/978-3-540-32827-8

Wong, K. K. (2013). Partial Least Squares Structural Equation Modeling ( PLS-SEM ) Techniques Using SmartPLS. Marketing Bulletin, 24, 1-32. 